\title{
Makna Simbol Gelar Raja Dalam Masyarakat Adat Bali
}

\author{
Sangayu Ketut Laksemi Nilotama \\ Fakultas Seni Rupa dan Desain, Universitas Trisakti, Jakarta. \\ Ilmu Seni dan Desain, Institut Teknologi Bandung
}

\begin{abstract}
Through the 18th and the 19th century, the position of Balinese King (Dewa Agung Jambe) was so important that he held power in both Bali and Lombok island, and he regognized by the title Sesuhunan Bali and Lombok. Dewa Agung Jambe politically and culturaly had several titles that were influential to the harmony of his sociaty livinghood. The titles of the king are related to the symbols that have sacred and trancendent meanings. Dewa Agung was God's Awatara, symbolized or varous forms such as ornaments, carvings, sacrad Balinese writings and letters, bulidings, even the deceased's container or coffin ( Bade beratap tumpang 11). The purpose of this essay was to explore the meanings and symbols that were the reflection of those king titles, to prevent the possibility of misuse from the original function of those sacred symbols. This has been a cultural research with the stucture of the history of Balinese Kingdom traditional sociaty that embranced Hindu. The funtion of these symbols are for strengthening the personality and morality, especialy in the aspect of arts and design. Therefore, it is important to continue preserving, harmonizing these tradisional symbols especially ones that have religious, sacrad, even spiritual values.
\end{abstract}

Keywords: king/Dewa Agung; symbols; titles.

\section{$1 \quad$ Pendahuluan}

Raja atau Dewa Agung Jambe pada masa keratonan di Bali sangat berpengaruh dan berkuasa. Menurut Sartono, raja selaku penguasa, berorientasi kepada sistem kepemimpinan tradisional, yaitu dalam menentukan penggantinya selalu berdasarkan atas status yang didapat dari keturunan. Para keturunan bangsawan Bali (kstaria) sepanjang hidupnya terbiasa dengan citra sang pemimpin. Perjalanan sejarah kerajaan di Bali terbagi dalam 3 (tiga) periode penting berdasarkan tahun masehi, yaitu: periode Samprangan (1343-1630), periode Gelgel (1630-1650), dan periode Klungkung (1686-1908).

Pada awalnya struktur politik dan hukum ketatanegaraan Bali dan Lombok merupakan negara kesatuan dengan satu pusat pemerintahan berkedudukan di ibu kota Gelgel, tetapi di masa periode Klungkung struktur politik dan ketatanegaraan Bali berbentuk persekutuan atau perserikatan dengan Dewa Agung Jambe dari Klungkung sebagai penguasa pemerintahan, atau junjungan (sesuhunan). 


\section{Pemberian Gelar Raja}

Pada permulaan abad XIX setelah memasuki periode Klungkung, sistem kerajaan di Bali terpecah menjadi 8 (delapan) kerajaan kecil, yaitu: Karangasem, Klungkung, Badung, Tabanan, Gianyar, Bangli, Buleleng, dan Mengwi. Dari delapan raja yang berkuasa, raja Klungkung memiliki pengaruh dan kedudukan yang paling utama. Selanjutnya Dewa Agung Jambe memperoleh gelar Sesuhunan Bali dan Lombok, pengertian sesuhunan (bahasa Bali) yang berarti junjungan (segala perintahnya selalu dijunjung tinggi rakyatnya). Kemudian gelar Dewa Agung ditambah lagi dengan gelar Betara (dipersamakan dengan awatara Tuhan), sehingga gelar Dewa Agung menjadi menjadi Betara Sesuhunan (awatara Tuhan yang dijunjung tinggi). Gelar ini selanjutnya untuk menunjukkan luas dan besarnya kekuasaan raja Klungkung, menjadi Betara Dewa Agung Sesuhunan [1].

Menurut Arsip Nasional Republik Indonesia, pemberian gelar sesuhunan diberikan terhadap status raja Klungkung hanya dikenal dalam perjanjian antara Klungkung dengan Belanda saja. Pemberian gelar ini oleh pemerintah Belanda cukup beralasan, Belanda sudah mengetahui bahwa status dan peranan Dewa Agung tidak sebesar yang pernah dimiliki raja-raja pada periode Gelgel. Disatu pihak tindakan Belanda ini merupakan tuntutan sikap politik subyektif yang diterapkan Belanda di seluruh Indonesia. Pemberian gelar sesuhunan sebenarnya mencerminkan pengakuan bahwa kekuasaan Dewa Agung dalam bidang politik dan ketatanegaraan terbatas hanya di dalam wilayah kerajaan Klungkung.

Pemberian gelar ini juga turut memperkuat kedudukan bahwa raja ini merupakan keturunan langsung dari raja Sri Kresna Kepakisan yang diangkat oleh raja Jawa (kerajaan Majapahit) saat patih Gajah Mada menguasai Bali, dan pewaris keraton Gelgel. Untuk itu dapat dikatakan bahwa rakyat Klungkung (khususnya) menganggap dirinya sebagai pewaris pulung dan keturunan lurus dari dinasti Kresna Kepakisan dan secara moral bertanggung jawab untuk menjaganya.

Pada paswara antara kerajaan Klungkung, Gianyar, Bangli, Payangan, Badung, dan Mengwi tahun Ĉaka 1759 (1837 M), raja Klungkung memperoleh legitimasinya kembali. Gelar Ida Cokorda Ida I Dewa Agung menempatkan kembali raja Klungkung pada status yang tertinggi sebagai penguasa selama hayat dikandung badan (sasungkuning urip). Pemberian gelar atas dukungan raja-raja lainnya diperlukan untuk bersama-sama menghadapi ancaman Belanda terhadap kerajaan-kerajaan di Bali. 
Peran raja Klungkung sangat penting, setiap perjanjian kontak dan kontrak dengan Belanda, harus sepengetahuan, pertimbangan dan persetujuan raja.
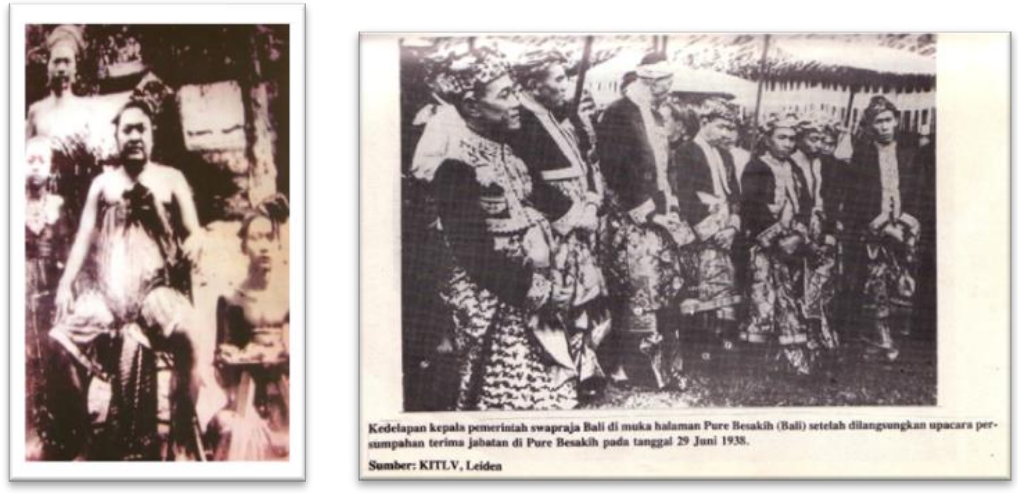

Gambar 1 Dewa Agung Jambe dan kanan-kedelapan raja-raja Bali. (sumber : Museum Kertagosa).

\section{Simbol pada Masyarakat Bali}

Pada dasarnya kehidupan masyarakat Hindu Bali sangat diwarnai oleh aktivitas simbolik. Setiap aktivitas terutama yang berkaitan dengan ritual keagamaan selalu diiringi dengan pesan-pesan simbolik. Simbol dalam pengertian agama Hindu terikat antara nilai-nilai Hindu, teologi Hindu, prilaku sosial, dan simbolsimbol agama Hindu. Simbol-simbol merupakan ekspresi untuk mendekatkan diri manusia dengan-Nya. Simbol-simbol tersebut berupa arca atau pretima untuk dewa-dewa, vahana dewata atau kendaraan dewa-dewa, bangunan suci sebagai stana untuk memuja-Nya, para devata atau roh suci leluhur. Simbolsimbol juga dapat berupa mantra, mudra, yantra, rerajahan, huruf-huruf suci, juga persembahan suci berupa sesajen yang beraneka ragam, dan bentuk lainnya [2].

Pulau Bali yang berdasarkan sejarahnya merupakan suatu pulau yang masyarakatnya beragama Hindu, memiliki karakter khusus dalam aktivitas kehidupan sehari-hari dan aktivitas ritual keagamaan selalu diiringi dengan rangkaian simbol-simbol tersebut diatas. Setiap simbol memiliki makna tertentu, dengan memahami makna simbol umat Hindu kemudian mengembangkan apresiasi terhadap simbol-simbol tersebut. Sehingga tidak mengherankan bila berkunjung ke Bali, setiap saat ditemukan perempuanperempuan berkain dan berkebaya menghaturkan sesajen (Canang-rangkaian janur yang ditaburi bunga) ditempat-tempat khusus seperti perempatan jalan, tempat peribadatan, di depan rumah atau tempat usaha mereka dan sebagainya. 
Kegiatan seni budaya juga selalu menghiasi aktivitas kehidupan keagamaan, seperti persembahan tari sakral atau tari wali, sebagai salah satu wujud persembahan mereka kepada Hyang Widi Wasa.

Periode Samprangan dan Gelgel (berakhir thn.1651). Gelar "Dalem" = orang dalam- beliau yang paling dihormati dan dimuliakan.

Tanda pengaruh Jawa Majapahit penerus dinasti Sri Kresna Kepakisan.
Ida Cokorda Ida I Dewa Agung

(Sasungkuning urip)

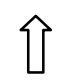

Betara Dewa Agung Sesuhunan<smiles>C1=CC=C1</smiles>

Betara Sesuhunan

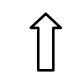

Betara

†

Sesuhunan

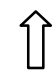

Ida I Dewa Agung

Agung”, hilangnya pengaruh Jawa, timbulnya unsur Bali. Tanda perubahan status dari politik ketatanegaraan menjadi non politik dan religius. Dewa Agung simbol perwakilan Dewa atau Betara (Awatara Tuhan)

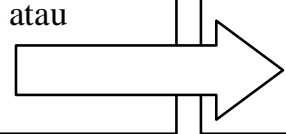

Gambar 2 Perubahan Gelar Dewa Agung Klungkung.

Raja atau Dewa Agung merupakan tokoh sentral yang disakralkan masyarakatnya. Dewa Agung selain sebagai sesuhunan, dia juga merupakan simbol perwakilan Dewa atau Betara di bumi (awatara Tuhan). Dewa Agung bertindak sebagai kepala agama dan hakim tertinggi, yang menjadi simbol kesucian, kesaktian, kebenaran, dan kebijaksanaan. Dalam posisi raja sebagai hakim tertinggi, raja memiliki simbol tersendiri dan khusus. Dalam proses persidangan adat raja Klungkung memiliki tempat duduk khusus dengan pegangan tangan dengan simbol atau lambang singa atau singha. Untuk para pendeta (bhagawanta) kursi dengan simbol pegangan tangan berbentuk kepala lembu, sedangkan untuk para jaksa dengan simbol berbentuk kepala naga. Simbol-simbol ini hanya terdapat di puri Smarapura Klungkung yang sampai saat ini dapat ditemukan di lokasi Bale persidangan adat yang disebut Bale Kertagosa. 


\section{$4 \quad$ Metoda Penelitian}

Tulisan ini bertujuan untuk menghasilkan informasi tentang simbol-simbol yang beraneka ragam di dalam sejarah kebudayaan Bali yang berkaitan dengan dinamika kehidupan sosial budaya masyarakat adat Bali khususnya pada masa kerajaan dahulu. Tulisan ini bertitik tolak pada pemikiran bahwa makna simbolik raja terutama penerus keturunan bangsawan di Bali sangat tergantung dari kelangsungan tatanan kehidupan masyarakat adat dan aktivitas ritual keagamaan berdasarkan ajaran agama Hindu. Untuk itu tulisan ini bertujuan untuk mengetahui makna dan hakekat yang terkandung dalam simbol-simbol yang berhubungan dengan raja Bali, dan untuk mencegah terjadinya kemungkinan penyalahgunaan fungsi dari simbol-simbol tersebut. Untuk memperjelas arah penelitian akan disajikan bentuk penelitian yang menguraikan pengertian simbol dalam beberapa bidang keilmuan, menggambarkan keterikatan antara nilai-nilai Hindu, perilaku sosial dan simbol-simbol agama Hindu terutama yang berkaitan dengan peran raja sebagai pimpinan spiritual dan pimpinan kebudayaan.

Penelitian kualitatif dengan kajian budaya ini berupaya mendapatkan data-data, oleh karenanya dapat dilakukan dengan berbagai setting, berbagai sumber dan berbagai cara. Bila dilihat dari settingnya data dapat diperoleh dan dikumpulkan pada setting alamiah (natural setting) seperti di sekolah, di tempat upacara, seminar, diskusi dan lain-lain. Bila data diperoleh dari sumber, maka pengumpulan data dapat mempergunakan sumber primer, dan sumber sekunder. Menurut Djaman Satori, sumber primer dapat memberikan langsung memberikan data kepada peneliti, sumber sekunder adalah merupakan sumber yang tidak langsung memberikan data. Dari segi cara atau teknik pengumpulan data dilakukan dengan observasi partisipasi (participant observer), wawancara yang mendalam (in-depth interview), diskusi, dokumentasi, dan gabungan keempatnya.

\section{$5 \quad$ Tentang Simbol}

Menurut Yudha Triguna, secara etimologis simbol adalah suatu hal atau keadaan yang merupakan pengantaran pemahaman terhadap objek. Manifestasi serta karakteristik simbol tidak terbatas pada pada isyarat fisik, tetapi dapat juga berwujud penggunaan kata-kata, yakni simbol suara yang mengandung arti bersama serta bersifat standar [3].

Secara ontologi simbol dan simbolisasi bersifat dikotomis. Pemahaman pertama simbol dan simbolisasi berkaitan dengan yang imanen - ada dalam diri manusia saja. Pemahaman lainnya symbol merujuk kepada hal yang transenden (yang 
mengatasi objektivikasi) - adanya dialog manusia dengan 'yang lain', sehingga simbol tidak hanya horizontal-imanen, tetapi juga vertikal-transenden.

Goethe menyatakan lebih dari seabad lalu bahwa 'dalam simbolisme sejati, yang-khusus mengungkapkan yang-universal bukan sebagai impian atau bayangan, melainkan sebagai wahyu yang hidup, dari yang tidak dapat diduga. Ia juga menyatakan bahwa sebuah simbol sesungguhnya "mengambil bagian dalam realitas yang membuatnya dapat dimengerti”.

\section{A.N.Whitehead dalam bukunya Symbolism menyatakan:}

Pikiran manusia berfungsi secara simbolis apabila beberapa komponen pengalamannya menggugah kesadaran, kepercayaan, perasaan, dan gagasan mengenai komponen-komponen lain pengalamannya. Perangkat komponen yang terdahulu adalah 'simbol' dan perangkat komponen membentuk "makna" simbol. Keberfungsian organis yang menyebabkan adanya peralihan dari simbol kepada makna itu akan diseburt refensi.

Arnold Toynbee dalam bukunya A Study of History lebih memusatkan perhatian kepada dunia intelek.

Sebuah simbol tidak identik atau ko-ekstensif dengan objek yang disimbolkannya. Seandainya demikian halnya, simbol tersebut tidak akan menjadi symbol barang itu, melainkan barang itu sendiri. Adalah salah anggapan bahwa sebuah symbol dimaksudkan untuk menjadi reproduksi barang: sebenarnya simbol dimaksudkan bukan untuk merepro objeknya, melainkan untuk meneranginya. Simbol yang efektif adalah simbol yang member terang, dan simbol yang efektif merupakan bagian mutlak perlengkapan intelektual kita. Jika sebuah simbol harus bekerja dengan efektif sebagai alat untuk tindakan intelektual - artinya, sebagai 'model' - simbol itu harus disederhanakan dan dipertajam sehingga menjadi seperti sesuatu yang mirip peta-sketsa dari sebuah realitas yang hendak diwakili oleh simbol sebagai pemandu - sebuah peta-sketsa, jadi bukan sebuah fotograf yang diambil dari pesawat terbang.

Melihat beberapa pendapat mengenai simbol, bagi Whitehead simbol mengacu kepada makna, bagi Goethe simbol menggambarkan yang universal, dan bagi Toynbee simbol menyinari realitas [4].

\section{Simbol dalam Kekuasaan Raja}

Pada awal abad XIX bentuk dan susunan pemerintahannya bersifat feodal, raja memiliki kekuasaan mutlak yang tidak terbatas. Raja adalah penguasa 
pemerintahan tertinggi yang juga bertindak sebagai kepala agama dan hakim tertinggi. Thomas Aquinas dalam buku Pemerintahan Para Raja menjelaskan perbedaan antara pemerintahan despotic dan pemerintahan yang sah.

Pemerintahan despotic adalah pemerintahan yang hanya berdasarkan kekuasaan saja. Sedangkan pemerintahan politik yang sah harus sesuai dengan kodrat masyarakat orang-orang bebas. Jadi bila kesatuan orang-orang bebas dibimbing kearah kesejahteraan umum masyarakat, pemerintahan ini akan bersifat betul dan adil sebagaimana mestinya bagi orang-orang yang bebas. Tetapi bila pemimpin tidak mengusahakan kesejahteraan umum masyarakat, melainkan kepentingan pribadi sang pemimpin, pemerintahan itu tidak adil dan bertentangan dengan kodrat. Kekuasaan itu akan stabil bila sah secara moral [5].

Rakyat sangat hormat dan patuh tidak terbatas terhadap segala perintahnya, ini merupakan salah satu ciri khas sikap masyarakat Bali saat itu. Menurut Ide Anak Agung Gde Agung, para raja Bali hidup sangat sederhana tidak kaya-raya seperti para sultan di Malaya atau para Maharaja di India, mereka memang menghuni istana (puri) yang dikelilingi tembok tinggi dan tebal, tetapi bangunan-bangunan yang ada di dalamnya tidak menunjukkan kemewahan [6]. Hal ini dapat di buktikan dengan beberapa peninggalan puri tersebut masih ada di Bali terutama lingkungan puri Smarapura Klungkung yang telah hancur akibat perang Puputan pada 28 April tahun 1908.

Dalam tatanan kehidupan masyarakat Bali dikenal penamaan rumah atau tempat tinggal bagi para bangsawan yang disebut Puri. Puri (Agung) merupakan kompleks tempat tinggal para bangsawan, dan puri Agung pun merupakan simbol tempat tinggal raja dan keluarganya.

Raja Klungkung Dewa Agung Jambe adalah simbol Dewa atau Betara di dunia, dan Dewa Agung juga merupakan simbol Awatara. Dalam nilai-nilai ajaran agama Hindu, menurut S.Radhakrishnan dalam bukunya Indian Philosophy volume 1, kata dewa atau 'deva' berarti sangat dimuliakan sesuai dengan alamnya dan digunakan untuk menunjukkan berbagai hal yang berbeda-beda. Dikatakan pula dalam terjemahan mantram Taittiriya Upanisad bahwa:

(seorang ibu adalah dewa, seorang bapak adalah dewa, seorang guru adalah juga dewa, dan para tamupun adalah dewa).

Keempat dewa itu adalah para dewa yang mempunyai badan kasar [7].Menurutnya kata deva mengandung 10 (sepuluh) arti dari urat kata divu, yaitu: (1) bermain, (2) penaklukan, (3) aktivitas pada umumnya, (4) kemuliaan/ keagungan, (5) penghormatan, (6) menyenangkan, (7) kerinduan, (8) tidur, (9) keindahan (kanti) dan (10) kemajuan. Arti atau makna kata dewa itu meliputi 
dua hal yang sama, perbedaannya antara dewa (Tuhan Yang Maha Esa) dengan dewa (para dewa) adalah: seluruh dewa atau devata menerima sinar Tuhan Yang Maha Esa (merupakan sinar-Nya) sedangkan Tuhan Yang Maha Esa memancarkan sendiri sinar-Nya.
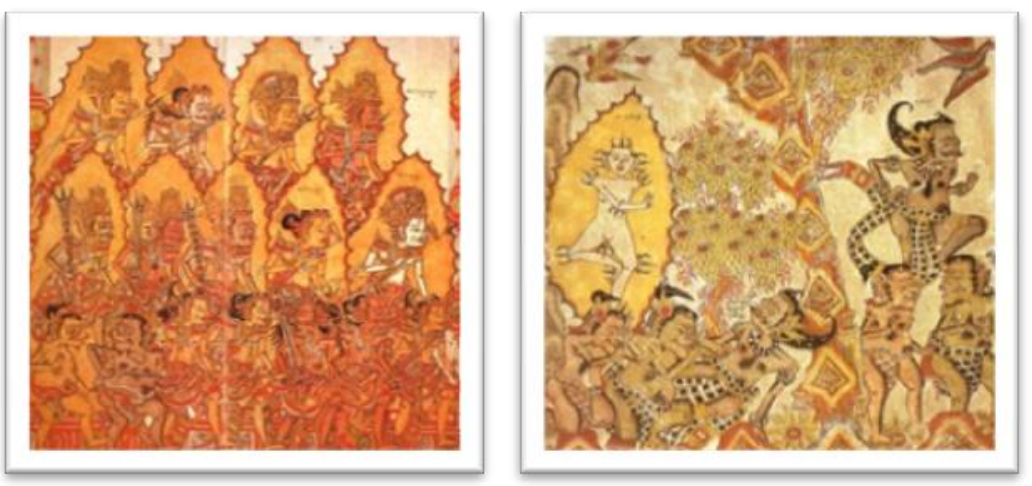

Gambar 3 Lukisan wayang Kamasan- Bale Kertagosa, kiri - simbol-simbol para dewa yang menerima sinar-Nya. Kanan - simbol Acintya - simbol Sang Hyang Widi Wasa/Tuhan Yang Maha Esa, memancarkan sendiri sinar-Nya.
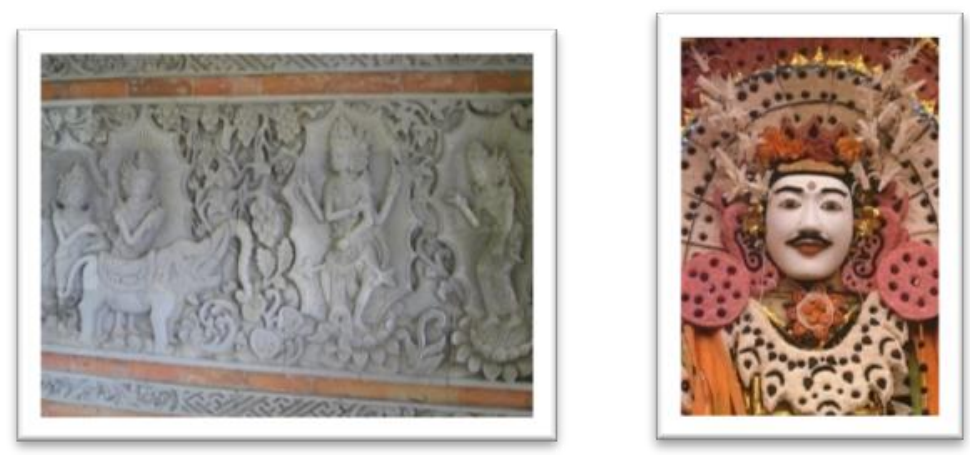

Gambar 4 Simbol pemujaan terhadap raja/dewa atau disebut Istadevata: mempergunakan figur-figur dewa dewi dalam bentuk ukiran/ relief, patung, dan ragam hias lainnya.

Dalam bukunya Titib menyatakan [2] dalam kitab suci Weda, Tuhan Yang Maha Esa disebut dewa atau devatā, berarti cahaya, berkilauan, sinar gemerlapan yang semua itu ditujukan kepada manifestasi-Nya (Gambar 2), juga ditujukan kepada matahari atau langit, termasuk api, petir atau fajar [8]. Dewa juga berarti mahluk sorga atau yang sangat mulia [9]. Dalam kitab Nirukta VII.4 terdapat syair mengatakan terjemahannya adalah:

Oleh karena demikian tinggi makna dan ciri khas dari devatā (dalam hal ini Tuhan Yang Maha Esa). Yang merupakan jiwa alam semesta yang dipuja 
dengan berbagai pujian. Lainnya, para dewa (disebutkan di dalam kitab suci Veda), hanyalah bagian dari manifestasi-Nya. (dari Jiwa Yang Agung itu). Para dewa tampil dengan aneka wujudnya oleh karena berbagai aktivitas-Nya (yang berlipat ganda). Kereta (ratha) adalah deva (Jiwa dari alam semesta), kuda-kuda kereta adalah dewa adalah cahaya-Nya. Panah-panah-Nya adalah dewa, cahayaNya adalah jiwa-jiwa yang sama. Jiwa itu adalah dewa).

Sedangkan istilah Betara atau Battara/Battari (dewa dewi Hindu), sangat dikenal di Bali /Indonesia. Istilah awatara atau avatara adalah ditujukan untuk para leluhur. Kata Bhattara dalam bahasa Sansekerta, berasal dari kata bhatta (bhattr) yang artinya: yang melindungi, tuan, atau raja. Kata Battara berarti mereka yang sangat dihormati karena fungsinya sebagai pemimpin dan pelindung umat manusia [10]. Istilah dewa dewi dan battara adalah identik, karena fungsi dari mereka adalah untuk melindungi umat-Nya. Raja atau Dewa Agung sebagai awatara (Battara) merupakan sosok yang sangat dihormati dan diagungkan karena fungsinya sebagai pimpinan dan pelindung rakyatnya, dan Dewa Agung dapat tampil dalam berbagai aktivitas atau manifestasi Tuhan (pencipta, pelindung, dan pelebur). Dewa Agung merupakan Jiwal cahaya yang terdapat di bumi menjaga keselarasan dan keharmonisan kosmos.

Tabel 1 Ke-33 Dewa-dewi dalam teologi Hindu.

\begin{tabular}{llll}
\hline \multicolumn{1}{c}{ Dewa Astavasu } & \multicolumn{1}{c}{$\begin{array}{c}\text { Dewa } \\
\text { Ekadasarudra }\end{array}$} & \multicolumn{2}{c}{ Dewa Dvadasaditya } \\
\cline { 3 - 4 } & & \multicolumn{1}{c}{ Trancendent } & \multicolumn{1}{c}{ Immanent } \\
\hline $\begin{array}{l}\text { 1. Anala, dewa api. } \\
\text { 2. Dhava, bumi }\end{array}$ & $\begin{array}{l}\text { 1. Ajaikapat } \\
\text { 2. Ahirbudhnya }\end{array}$ & $\begin{array}{l}\text { 1. Mitra, sahabat } \\
\text { 2. Aryaman, } \\
\text { mengalahkan } \\
\text { musuh }\end{array}$ & $\begin{array}{l}\text { 7. Varuna, langit } \\
\text { 8. Daksa, ahli }\end{array}$ \\
3. Anila, angin & 3. Virupaksa & $\begin{array}{l}\text { 3. Bhaga, } \\
\text { pemurah } \\
\text { 4. Tvastr, } \\
\text { pembentuk }\end{array}$ & 9. Amsa, bebas \\
4. Prabhasa, langit & 4. Suresvara & 10. Savitr, pelebur \\
5. Pratyusa, matahari & $\begin{array}{l}\text { 5. Jayanta } \\
\text { 6. Aha, antariksa }\end{array}$ & $\begin{array}{l}\text { 6. Bahurupa } \\
\text { 6. Vivasvat, } \\
\text { gemerlapan }\end{array}$ & 11. Sukra, kekuatan \\
7. Candra, bulan & $\begin{array}{l}\text { 7. Aparajita } \\
\text { 8. Savitra }\end{array}$ & meresapi \\
8. Druva, planet & $\begin{array}{l}\text { 9. Tryambaka } \\
\text { 10. Vaivasvata } \\
\text { 11. Hara }\end{array}$ & & \\
\hline
\end{tabular}


Dalam teologi Hindu ditemukan banyak nama untuk para dewa, disebutkan dalam kitab suci RgWeda: menyebutkan jumlah dewa-dewa sebanyak 33 dewa [11]. Jumlah 33 dewa adalah merupakan simbol tenaga kosmos. Mereka menguasai Tri Bhuwana (Bhur, Bhwah, Swah Loka) yaitu: bumi, langit, dan surga. Ke 33 dewa ini terbagi berbagai tugas atau aktivitas-Nya: 8 Vasu (Astavasu), 11 Rudra (Ekadasarudra), 12 Aditya (Dvadasaditya)- terdiri dari dua kelompok dewa, 6 dewa transcendent dan 6 dewa immanent, serta Indra dan Prajapati. Para dewa dilukiskan selalu berwajah muda (nirjara, para dewa tidak mengalami umur tua, karena mereka minum amrta/air kehidupan, wajahnya selalu tampan).

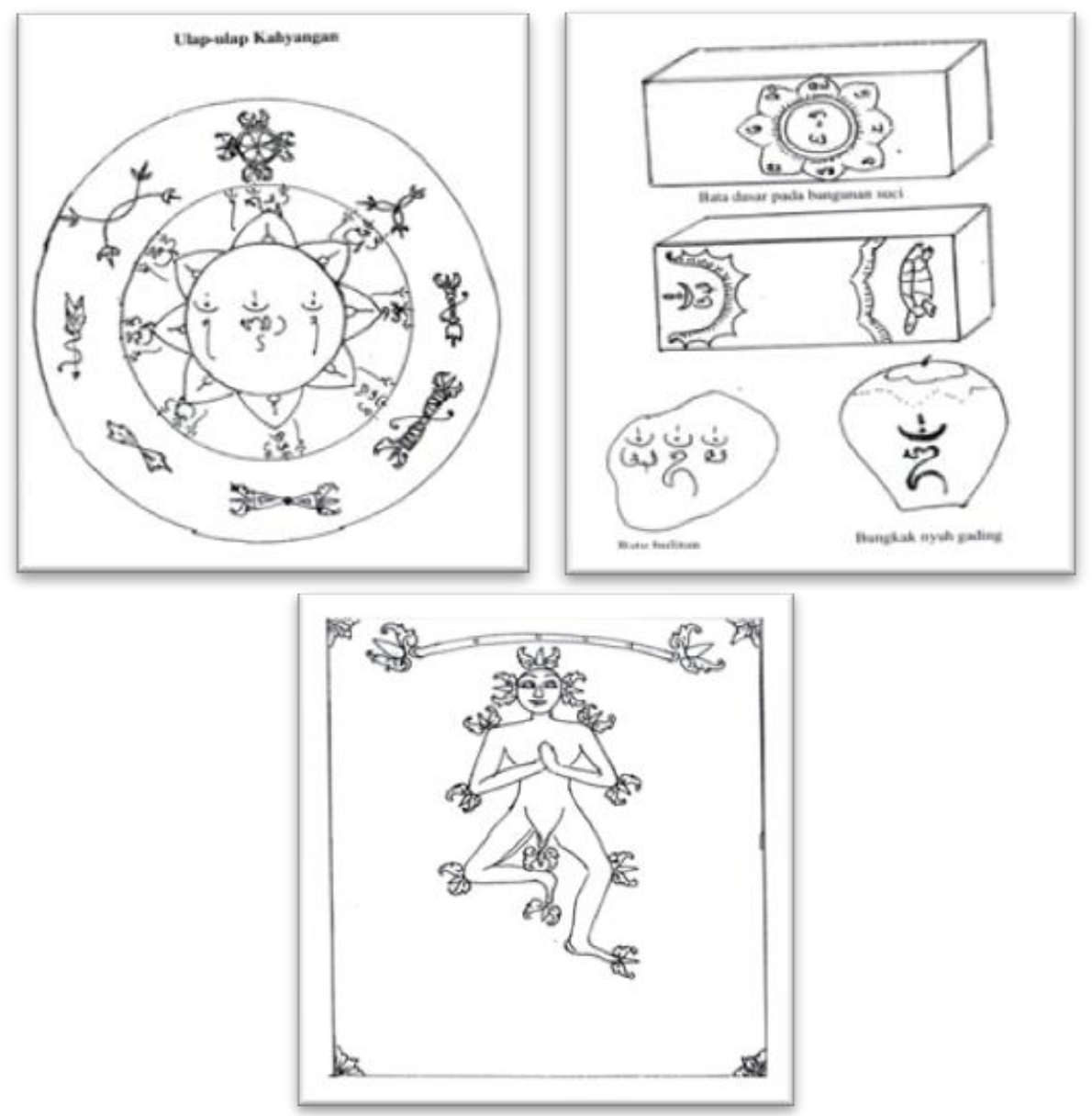

Gambar 5 Simbol-simbol juga dapat berupa mantra, mudra, yantra, rerajahan, huruf-huruf/aksara suci yang terdapat dalam sarana upacara keagaman. 
Selain simbol berbentuk dewa dewi, dalam masyarakat adat Bali simbol bunga memegang peranan penting dalam keselarasan dan keharonisan kosmos. Bunga selalu dipergunakan sebagai sarana persembahan dalam setiap ritual keagamaan. Bunga dipergunakan untuk menunjukkan kesucian hati di dalam memuja Tuhan Yang Maha Esa, oleh karenanya bunga yang dipergunakan adalah bunga yang segar, harum, tidak berserangga, tidak ternoda.

Berdasarkan lontar Aji Kembang dan lontar Siwa Pakarana Dewata Nawasanga digambarkan atau disimbolkan dengan bunga Tunjung atau bunga teratai. Bunga ini dilukiskan sebagai padma astadala, simbol alam semesta stana Hyang Widhi Wasa (Tuhan Yang Maha Esa). Dalam bahasa Kawi bunga disebut pangkaja atau sarasija (bunga yang tumbuh dari lumpur). Filosofi bunga ini sangat istimewa, dia seolah-olah dapat hidup dalam tiga dunia: akarnya terpancang di tanah, tangkai dan ujung daunnya di air, dan bunganya menyembul di udara. Dalam lontar Dasasana bunga teratai disebut raja kusuma atau rajanya bunga-bungaan dan dipandang sebagai bunga yang terbaik. Sedangkan dalam kitab Jnana Sidhanta bunga yang mekar dan wangi itu disebutkan sebagai lambang aksara suci.

Berkaitan dengan upacara yang berhubungan dengan spiritual seperti upacara Pelebon atau upacara pembakaran jenasah biasanya dilaksanakan dalam tingkatan yang besar (uttama) dan umumnya dipergunakan bagi para raja atau (mantan raja) dari kasta Ksatria dan juga bagi para pendeta atau kasta Brahmana. Seorang raja yang wafat biasanya wadah jenasah atau di sebut Bade beratap tumpang 11 (sebelas). Bade dipergunakan raja, keluarga bangsawan dan para pejabat kerajaan/ patih. Bade dapat saja mempergunakan atap tumpang sembilan, atap tumpang tujuh, atap tumpang lima, tiga, dan satu. Bade adalah lambang atau simbol "bhuwana agung" dengan puncak gunung yang disimbolkan melalui atap bertumpang tersebut, jenasah disimbolkan diletakkan diatas menara, dengan makna diharapkan roh (atma) orang tersebut akan segera mencapai alam sorga (kadewataan).

Bade/wadah jenasah seorang raja biasanya disertai dengan simbol Nagabandha. Naga merupakan lambang ikatan atau alat pengikat, atau alat penuntun bagi arwah seorang raja untuk mencapai sorga. Maksudnya dengan penuntun ini adalah untuk mengingatkan roh (atma) seorang raja untuk melepaskan diri terhadap ikatan duniawi.

Keadaan atma yang terikat dengan benda-benda duniawi (jasad) digambarkan dengan nagabandha. Filosofi nagabandha adalah mengikat unsur purusa (atma) dengan unsur pradana (jasad). Bali saat ini tidak dipimpin oleh raja, tetapi keturunannya tetap lestari dalam menjaga makna-makna simbol yang tersirat dalam setiap gelar yang disandangnya. 
Ada kemungkinan bade beratap tumpang sebelas akan hadir kembali, agar dapat dihayati oleh setiap generasinya.

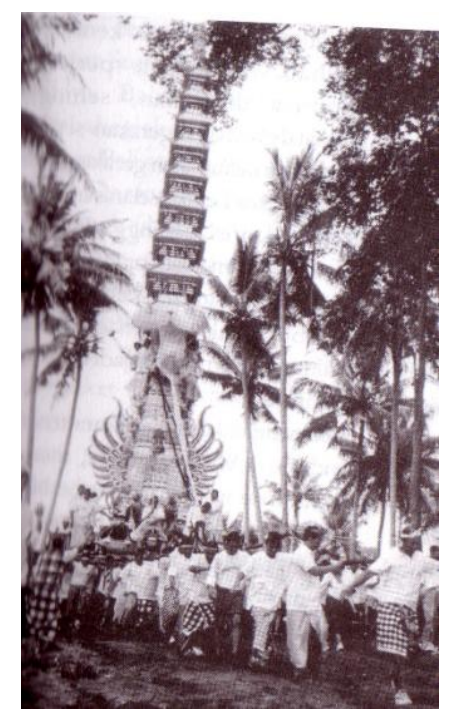

Gambar 6 Bade beratap Tumpang Sebelas untuk raja [12].

Dewa Agung Jambe sebagai hakim tertinggi, memiliki simbol tersendiri dan khusus. Simbol ini terlihat dalam bentuk satu buah kursi yang dihiasi ukiran motif dan bentuk tertentu. Dalam proses persidangan adat raja Klungkung memiliki tempat duduk khusus dengan pegangan tangan dengan simbol atau lambang singa atau singha. Untuk para pendeta (bhagawanta) kursi dengan simbol pegangan tangan berbentuk kepala lembu, sedangkan untuk para jaksa dengan simbol berbentuk kepala naga. Simbol-simbol ini hanya terdapat di puri Smarapura Klungkung yang sampai saat ini dapat ditemukan di lokasi Bale persidangan adat yang disebut Bale Kertagosa.

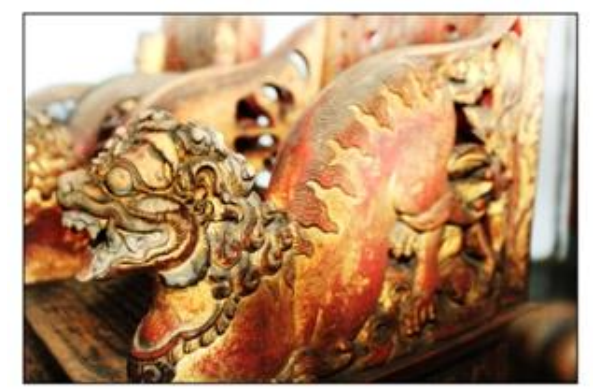

Gambar 7 Kursi bersimbol Singa/Singha untuk raja bersidang. 
Simbol singa adalah merupakan suatu vahana/ wahana/ kendaraan para dewata. Singa atau singha merupakan salah satu binatang mitos yang diyakini suci oleh umat Hindu. Beberapa arca berbentuk hewan lain yang dianggap bermuatan mitos adalah naga, naga bersayap, singa, harimau, burung garuda dan lainnya. Disamping itu singa di Bali popular dengan sebutan Barong. Singa atau Barong ini yang dikenal sebagai kendaraan dari dewi Durga.

Kata barong berasal dari barwang dalam bahasa Jawa kuno berarti beruang, beruang madu. Kata-kata ini ditemukan dalam cerita Ramayana, Sutasoma dan sebagainya. Singabarwang adalah untuk menunjukkan kehebatan kendaraan sang dewi. Wajah yang mirip dengan wajah barong di Bali disebut dengan nama Bhoma, dikaitkan dengan cerita raja raksasa Naraka, putra dewi Perthivi. Sehingga penggunaan simbol singa untuk raja dirasakan tepat karena sifat dari binatang ini adalah sebagai penjaga dan penguasa kosmos.

\section{$7 \quad$ Simpulan dan Saran}

Memahami makna setiap peristiwa sejarah berarti kita terikat oleh dimensi waktu, yaitu waktu lampau, waktu sekarang, dan waktu akan datang, atau ada awal, ada puncak, ada akhir. Terdapat dua Makna yang dapat dipetik dari upaya mengungkap makna simbolik ini yaitu budaya adat Bali dalam kerangka sejarah kerajaan, dan budaya dalam bentuk kepribadian bangsa Indonesia. Makna pertama menitik beratkan kepada dimensi waktu lampau untuk dapat dimaknai nilai-nilai historis bahwa Bali dalam sejarah kebudayaannya pernah memiliki suatu bentuk pemerintahan kerajaan yang besar, luhur dan agung. Makna kedua lebih kepada bagaimana memaknai dimensi saat ini dan yang akan datang. Pembangunan Bali saat ini semakin pesat, era globalisasi memasuki setiap sudut karya budayanya, nilai-nilai budaya asli harus bersaing dengan budaya teknologi. Simbol-simbol yang menyampaikan pesan tradisi dapat tergerus oleh pesan-pesan yang lebih mudah diserap logika. Simbol-simbol dalam masyarakat Hindu Bali seperti "didewakan" dan "disembah", masyarakat Hindu Bali bukan mengidentikkan benda sakral dengan dewa. Mereka meyakini sebagai dewa dan disembah, siapa yang "menghidupkan" atau "menjiwai" benda tersebut. Pada hakekatnya benda fisik hanyalah symbol untuk memudahkan umat "berkomunikasi" kepada Tuhan Yang Maha Esa. Umat Hindu tidak menyembah berhala, tetapi tetap menyembah Tuhan Yang Maha Esa/ Sang Hyang Widhi Wasa dalam berbagai perwujudannya lewat simbol-simbol. Dan umat Hindu Bali membuat simbol-simbol tersebut dengan cara yang sangat kreatif.

Fungsi simbol-simbol ini adalah untuk memantapkan kepribadian dan moralitas, khususnya di bidang seni dan desain,serta memupuk rasa kebersamaan, terutama dalam proses sakralisasi dan berfungsinya simbol-simbol tersebut dalam masyarakat adat Hindu Bali dan masyarakat pada umumnya. Oleh 
karenanya penting untuk tetap melestarikan, mengharmoniskan simbol-simbol tradisi yang terutama bermuatan religious, sakral, bahkan spiritual.

\section{Daftar Pustaka}

[1] Sidemen, Ida Bagus dan Tim Penyusun. 2001. Sejarah Klungkung (dari Smarapura sampai Puputan), Pemerintah Kabupaten Klungkung, Bali, p. 53.

[2] Titib. I Made. 2003. Teologi dan Simbol-simbol dalam Agama Hindu, Paramita, Surabaya, p. 1.

[3] Yudha Triguna,Ida Bagus Gde. 2000. Teori Tentang Simbol, Penerbit Widya Dharma, Denpasar Timur, Bali, p. 7.

[4] Dillistone, F.W. 2002. Daya kekuatan Simbol (The Power of Symbols), Pustaka Filsafat, Penerbit Kanisius, Yogyakarta.

[5] Magnis-Suseno, Frans. 1995. Mencari Sosok Demokrasi, Sebuah Telaah Filosofis, Gramedia Pustaka Utama, pp.5-6.

[6] Ida Anak Agung Gde Agung. 1989. Bali Abad XIX, Gadjah Mada University Press, Yogyakarta.

[7] Sarasvati, Dayananda, 1981, p. 93. Dikutip oleh I Made Titib dalam Teologi dan Simbol-simbol dalam Agama Hindu (2003)

[8] Muller.1969. p. 17. Dikutip oleh I Made Titib dalam Teologi dan Simbolsimbol dalam Agama Hindu (2003).

[9] Williams, Monier. 1990. p. 4925. Dikutip oleh I Made Titib dalam Teologi dan Simbol-simbol dalam Agama Hindu (2003).

[10] Williams, Monier. 1993. p. 745. Dikutip oleh I Made Titib dalam Teologi dan Simbol-simbol dalam Agama Hindu (2003).

[11] Macdonell. 1991. p. 19. Dikutip oleh I Made Titib dalam Teologi dan Simbol-simbol dalam Agama Hindu (2003).

[12] Tim Perumus Bali Post. 2004. Ajeg Bali: Sebuah Cita-Cita, Pustaka Bali Post, Denpasar-Bali, Indonesia, p. 41. 